Proceedings of the 7-th National Meeting of Synchrotron Radiation Users

\title{
Infrared Spectroscopic Identification of Chosen Dental Materials and Natural Teeth
}

\author{
W. HȨDZELEK ${ }^{a}$, R. WACHOWIAK ${ }^{b}$, A. MARCINKOWSKA $^{a, *}$ \\ AND L. DOMKA ${ }^{c}$ \\ ${ }^{a}$ Department of Prosthetic Dentistry, Poznań University of Medical Sciences \\ Poznań, Poland \\ ${ }^{b}$ Department of Forensic Medicine, Poznań University of Medical Sciences \\ Poznań, Poland \\ ${ }^{c}$ Department of Chemistry, Technological Center \\ Adam Mickiewicz University, Poznań, Poland
}

\begin{abstract}
Studies using solid phase infrared spectroscopy in the range of 400 to 4000 wave numbers were conducted in order to quickly identify solid tooth fragments and differentiate them from dental materials used in the dental practice. The frequently employed dental materials were evaluated. Natural chemical structure of permanent teeth obtained from donors of various ages provided the reference material. The infrared vibrations detected in infrared transmission spectra depended on the chemical structure of examined compound. Comparable distinctive peaks in infrared spectra of natural teeth and inorganic dental materials (porcelain) were exhibited. Analogous infrared spectra of dental materials consisting of organic matrix with inorganic fillers were found. In the case of acrylic materials specific organic groups were enhanced. The prepared database of infrared transmission spectra included 23 dental materials, facilitating their appropriate identification. Application of infrared spectroscopy allowed for a quick differential identification of typical dental materials produced from organic compounds for inorganic restorations (porcelain) and of tooth structure-resembling hydroxyapatite and its contaminate forms with fluoride and carbonate ions.
\end{abstract}

PACS numbers: 82.80.Gk, 33.20.Ea, 87.15.B-, 87.85.J-

\section{Introduction}

Dentists use a wide variety of dental materials in the oral rehabilitation. Therefore, the incidental release of a dental restoration or a spontaneous loss of a tooth structure fragment during mastication in some cases requires the lost fragment to be identified to confirm its origin.

*corresponding author; e-mail: agamarcink@poczta.onet.pl 
The sequelae of incidental mechanical injuries caused by dangerous solid fragments present in the mouth become crucial in case of patients exhibiting bruxing forces or habitual gum chewing. The forces are generated during clenching and grinding activities and may lead to release of teeth restorations. The problem involves identification and differentiation of a restoration fragment or a tooth structure from incidental contaminations. Mechanical injuries or potential tooth damage during assault provide a subject for numerous litigations against criminals and sometimes require appropriate identification of the material used in the dental treatment. Moreover, the identification of different materials in the oral cavity becomes essential in case of cadavers being victims of crimes, war, civil unrest, natural and mass disaster. Denture marking, especially on cobalt-chromium components, is a method, which facilitates victim identification in such circumstances [1].

Infrared (IR) spectroscopy is used as a method of choice for the case of solid chemical compound identification. This is the preferable method because of exact identification of chemical structures, especially of functional groups of organic compounds. The IR spectroscopy permits exact identification of dental materials, which were lost during mastication, and rapidly distinguishes these materials from fragments of teeth or other contaminations.

Raman and IR spectroscopy is the study of the scattering, reflection, absorption or transmission of radiation in the spectral range of 12500 to $10 \mathrm{~cm}^{-1}$ (wave numbers). The mid sub-region (4000-400 $\mathrm{cm}^{-1}$ ) of infrared spectrum is widely used in the analysis of chemical compound by IR spectroscopy, which obtains spectra by measuring the light absorption (or transmission). The Raman spectroscopy involves the scattering of radiation. However, some consider that both methods have been evaluated to be complementary in molecular vibrational analysis [2]. But the superiority of IR over Raman spectroscopy is a lack of the problems connected with fluorescence. The infrared technology has many useful applications. Among others, it is used in medicine as a tool for the analysis of chemical compounds (foods, pharmaceutical products, natural and synthetic biomaterials) and for the non-invasive analysis of body tissues [3-5].

Recently, the Raman spectroscopy is more widely applied in dental research [6]. A number of studies have been reported concerning properties of different dental materials using Fourier transform IR (FTIR) and Raman spectroscopy [7-17]. The possibility of histopathological examination of tissue specimens containing minimal amounts of foreign materials using infrared and Raman spectroscopy was previously described in dental literature [18]. Even the applications of mid infrared spectroscopy for in vivo diagnosis of diseases were discussed. According to some authors, the analysis of exposed surfaces like the skin, teeth or fingernails could be taken into account [3]. For the purpose of assessing mineral properties of calcified tissues i.e. bone and tooth, the vibrational spectroscopy, both IR and Raman, was performed $[19,20]$. Thus, the researchers used these 
methods to carry out comparisons of dental tissues including enamel and dentin and to examine the hydroxyapatite single crystallites [21, 22]. The chemical composition of apatite is significant because of the consequences, which ensue from different chemical and physical properties [23]. Moreover, the application of nearinfrared spectroscopy was also reported as a useful tool for the characterization of minerals, especially combined with hydroxyl groups or water bonded in the structure [24]. Some methods of the structural analysis were determined with the use of synchrotron radiation. These techniques play important role in materials science, medicine and geology and other fields of science [25]. The study of sound enamel using synchrotron X-ray microtomography (XMT) was performed to assess quantitative mineral distribution in occlusal pit and fissure of the teeth. These sites of the teeth are the most susceptible for primary carious lesions. Hence essential meaning such of examinations for dentistry [26].

The aim of the study was the rapid identification of solid tooth fragments and to distinguish them from the dental materials used in the dental practice.

\section{Materials and methods}

Twenty available and most frequently employed dental materials in our country were evaluated. Their names, type and composition are listed in Table. The existence of these materials as permanent restorations or prostheses were still observed in patient's mouth. The studies were performed on seven groups of solid substances of organic character filled with inorganic fillers: composite materials - Ariston pHc (Ivoclar Vivadent, Schaan, Liechtenstein), Charisma and Venus (Heraeus Kulzer, Hanau, Germany), Filtek Z250 (3M ESPE, Seefeld, Germany), Herculite XRV (Kerr, Orange, USA), Pertac II (ESPE, Seefeld, Germany), Tetric Ceram, Tetric Flow (Ivoclar Vivadent, Schaan, Liechtenstein), Valux Plus (3M ESPE, Seefeld, Germany), compomers - Compoglass F (Ivoclar Vivadent, Schaan, Liechtenstein), Dyract eXtra (Densply DeTrey, Konstanz, Germany), Hytac (ESPE, Seefeld, Germany), Twinky Star (VOCO, Cuxhaven, Germany), glass ionomers - GC Fuji IX (GC Europe N.V., Leuven, Belgium), Ketac-Molar (ESPE, Seefeld, Germany), Vitremer (3M, St. Paul, MN, USA), fissure sealants - Conseal f (SDI, Victoria, Australia), Helioseal F (Ivoclar Vivadent, Schaan, Liechtenstein) and typical inorganic materials: porcelain (originating from a patient's bridge), amalgam - Ardent Futura TopCap (AB Ardent, Arlandastad, Sweden) and acrylic materials - Duracryl (Spofa Dental, Dental a.s., Prague, Czech Republic), Villacryl H Plus (Zhermapol, Warszawa, Poland), artificial tooth (Dentex, Zduńska Wola, Poland). The differences between composite, compomer and glass ionomer are composition, properties and clinical application. Composites consist of organic polymer matrix and inorganic fillers but glass ionomers: special glasses, water and polyacrylic acid. Compomers (polyacid-modified composite resin) contain the same components as conventional dental composites and additional monomers with acidic functional group and contain no water. Natural 
Composition of the materials used in the present study.

\begin{tabular}{|c|c|c|}
\hline Materials & Types & Composition* \\
\hline Ariston pHc & $\begin{array}{l}\text { composite } \\
\text { material }\end{array}$ & 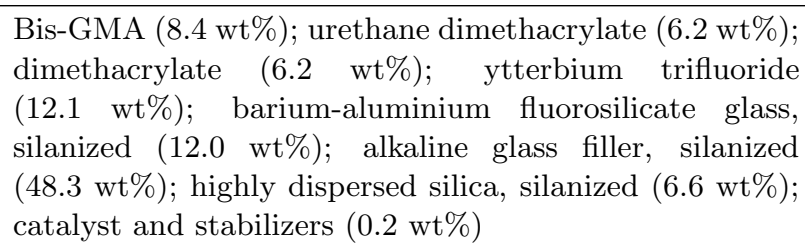 \\
\hline Charisma & $\begin{array}{l}\text { composite } \\
\text { material }\end{array}$ & $\begin{array}{l}\text { Bis-GMA ( } 64 \text { vol\%); barium aluminium fluoride glass, } \\
\text { highly dispersive silicon dioxide }\end{array}$ \\
\hline Venus & $\begin{array}{l}\text { composite } \\
\text { material }\end{array}$ & $\begin{array}{l}\text { Bis-GMA ( } 61 \text { vol\%); barium aluminium fluoride glass, } \\
\text { highly dispersive silicon dioxide }\end{array}$ \\
\hline Filtek Z250 & $\begin{array}{l}\text { composite } \\
\text { material }\end{array}$ & $\begin{array}{l}\begin{array}{l}\text { Bis-GMA, UDMA, Bis-EMA; zirconia/silica fillers } \\
(60 \text { vol } \%)\end{array} \\
\end{array}$ \\
\hline $\begin{array}{l}\text { Herculite } \\
\mathrm{XRV}\end{array}$ & $\begin{array}{l}\text { composite } \\
\text { material }\end{array}$ & $\begin{array}{l}\text { ethoxyloated Bis-GMA/TEGDMA; quartz, colloidal sil- } \\
\text { icon dioxide, barium glass ( } 78 \mathrm{wt} \% \text { ) }\end{array}$ \\
\hline Pertac II & $\begin{array}{l}\text { composite } \\
\text { material }\end{array}$ & $\begin{array}{l}\text { dimethacrylate monomers }(80 \mathrm{wt} \%) ; \text { ultrafine milled } \\
\text { quartz, highly dispersed silicon dioxide, yttrium fluoride }\end{array}$ \\
\hline Tetric Ceram & $\begin{array}{l}\text { composite } \\
\text { material }\end{array}$ & $\begin{array}{l}\text { dimethacrylates; ytterbium trifluoride; initiators, stabi- } \\
\text { lizers, pigments }\end{array}$ \\
\hline Tetric Flow & $\begin{array}{l}\text { composite } \\
\text { material }\end{array}$ & $\begin{array}{l}\text { Bis-GMA, urethane dimethacrylate, triethylene glycol } \\
\text { dimethacrylate }(35 \mathrm{wt} \%) \text {; barium glass, ytterbium tri- } \\
\text { fluoride, Ba-Al-fluorosilicate glass, highly dispersed sili- } \\
\text { con dioxide, spheroid mixed oxide ( } 64.6 \mathrm{wt} \%) \text {; catalysts, } \\
\text { stabilizers, pigments }(0.4 \mathrm{wt} \%)\end{array}$ \\
\hline Valux Plus & $\begin{array}{l}\text { composite } \\
\text { material }\end{array}$ & Bis-GMA, TEGDMA; zirconia-silica fillers (71 vol\%) \\
\hline Compoglass $\mathrm{F}$ & compomer & $\begin{array}{l}\text { urethane dimethacrylate, tetraethylene glycol } \\
\text { dimethacrylate, cycloaliphatic dicarboxylic acid } \\
\text { dimethacrylate }(22.75 \mathrm{wt} \%) \text {; ytterbium trifluoride, Ba- } \\
\text { Al-fluorosilicate glass, spheroid mixed oxide (77 wt } \%) \text {; } \\
\text { catalysts, stabilizers, pigments }(0.25 \mathrm{wt} \%)\end{array}$ \\
\hline Dyract eXtra & compomer & $\begin{array}{l}\text { urethane dimethacrylate (UDMA), carboxylic acid mod- } \\
\text { ified dimethacrylate (TCB resin), triethyleneglycol } \\
\text { dimethacrylate (TEGDMA), trimethacrylate resin, cam- } \\
\text { phorquinone, ethyl-4-dimethylaminobenzoate, butylated } \\
\text { hydroxyl toluene (BHT), UV stabilizer, strontium- } \\
\text {-alumino-sodium-fluoro-phosphor-silicate glass, highly } \\
\text { dispersed silicon dioxide, strontium fluoride, iron oxide, } \\
\text { titanium oxide pigments }\end{array}$ \\
\hline Hytac & compomer & monomers; $\mathrm{YF}_{3}, \mathrm{SiO}_{2},(\mathrm{Ca}, \mathrm{Zn}) \mathrm{FAlSi}(66$ wt\%) \\
\hline Twinky Star & compomer & - \\
\hline
\end{tabular}


TABLE cont.

Composition of the materials used in the present study.

\begin{tabular}{|c|c|c|}
\hline Materials & Types & Composition* \\
\hline GC Fuji IX & $\begin{array}{l}\text { glass } \\
\text { ionomer }\end{array}$ & $\begin{array}{l}\text { Powder: polyacrylic acid, aluminosilicate glass } \\
\text { Liquid: polyacrylic acid, proprietary ingredient }\end{array}$ \\
\hline Ketac-Molar & $\begin{array}{l}\text { glass } \\
\text { ionomer }\end{array}$ & $\begin{array}{l}\text { Powder: aluminium-calcium-lanthanum-fluorosilicate } \\
\text { glass, } 5 \% \text { polycarbonate acid } \\
\text { Liquid: polycarbonic acid, tartaric acid }\end{array}$ \\
\hline Vitremer & $\begin{array}{l}\text { glass } \\
\text { ionomer }\end{array}$ & $\begin{array}{l}\text { Powder: fluoroaluminosilicate glass } \\
\text { Liquid: aqueous solution of a modified polyalkenoic acid }\end{array}$ \\
\hline Conseal f & $\begin{array}{l}\text { fissure } \\
\text { sealant }\end{array}$ & $\begin{array}{l}\text { ester methacrylate (93 wt } \%) \text {; inorganic fillers, sodium } \\
\text { fluoride }(7 \mathrm{wt} \%)\end{array}$ \\
\hline Helioseal F & $\begin{array}{l}\text { fissure } \\
\text { sealant }\end{array}$ & $\begin{array}{l}\text { Bis-GMA, urethane dimethacrylate, triethylene glycol } \\
\text { dimethacrylate }(58.6 \mathrm{wt} \%) \text {; highly dispersed silicon } \\
\text { dioxide, fluorosilicate glass }(40.5 \mathrm{wt} \%) \text {; titanium diox- } \\
\text { ide, stabilizers, catalysts }(<1 \mathrm{wt} \%)\end{array}$ \\
\hline e.g. IPS Classic & porcelain & 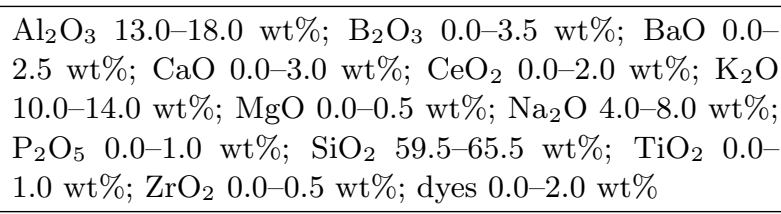 \\
\hline $\begin{array}{l}\text { Ardent Futura } \\
\text { TopCap }\end{array}$ & amalgam & Ag 40\%, Sn 31\%, Cu 29\% (420 mg alloy - $400 \mathrm{mg} \mathrm{Hg})$ \\
\hline Duracryl & $\begin{array}{l}\text { acrylic } \\
\text { material }\end{array}$ & $\begin{array}{l}\text { Powder: poly(methylmethacrylate), zinc oxide, pig- } \\
\text { ments Liquid: methylmethacrylate, hydroquinone, } \\
\text { dimethyl-para-toluidine }\end{array}$ \\
\hline $\begin{array}{l}\text { Villacryl H } \\
\text { Plus }\end{array}$ & $\begin{array}{l}\text { acrylic } \\
\text { material }\end{array}$ & $\begin{array}{l}\text { Powder: poly(methylmethacrylate), benzoil perox- } \\
\text { ide Liquid: methylmethacrylate (MMA) }>90 \% \text {, } \\
\text { (EGDMA) }<10 \%\end{array}$ \\
\hline
\end{tabular}

*composition according to the manufacturer: Charisma, Venus, Filtek Z250, Tetric Ceram, Tetric Flow, Valux Plus, Compoglass F, Dyract eXtra, Vitremer, Conseal f, Helioseal F, IPS Classic, Ardent Futura TopCap, Duracryl, Villacryl H Plus and according to the references: Ariston pHc [27], Herculite XRV [28], Pertac II [29, 30], Hytac [31], GC Fuji IX, Ketac-Molar [17].

chemical structure of permanent and deciduous teeth obtained from donors of various ages provided the reference material. Four permanent premolars and molars due to caries and two deciduous teeth for orthodontic purposes were extracted. The specimens were obtained from sound parts of these teeth. As a comparison to natural teeth and inorganic compounds pure $\mathrm{SiO}_{2}, \mathrm{CaCO}_{3}$ and $\mathrm{Ca}_{3}\left(\mathrm{PO}_{4}\right)_{2}$ (Cerasorb, Curasan, Kleinostheim, Germany) were analyzed.

In the study potassium bromide $(\mathrm{KBr})$ technique disk has been used in the identification procedures. The quantity of about $6 \mathrm{mg}$ dry tested compound was 
mixed with the alkali halides i.e. potassium bromide of about $250 \mathrm{mg}$ and ground mechanically in the agate ball mill. The sample had to be ground until particle size was smaller than $1 \mu \mathrm{m}$. The mixture was exposed to the pressure of approximately 10 tons in a press to produce an optically thin disk $(\oslash 14 \mathrm{~mm})$. A vacuum helped to retain dry conditions and smooth disk formation. It is difficult to achieve an ideal sample, which is clear, visually transparent and homogeneous. In the research solids i.e. dental materials were examined as dispersions in other solids. The studies were conducted using solid phase infrared spectroscopy in the mid-infrared spectral range. It is a method of choice for the case of solid chemical compound identification. The infrared transmission spectra database for fragments of natural teeth and various dental materials permitted to distinguish them from solid impurities of a non-dental origin which could manifest during mastication. Double-beam dispersive IR spectrometer Bruker IFS 113 (Ettlingen, Germany) offering the spectral range of $25-2.5 \mu \mathrm{m}$ was applied to our study, which utilized the selected range of 400 to 4000 wave numbers $\left[\mathrm{cm}^{-1}\right]$. The spectral resolution of our spectrometer was $2 \mathrm{~cm}^{-1}$.

\section{Results}

The solid phase ( $\mathrm{KBr}$ disk) infrared spectroscopy in the spectral range of 400 to 4000 wave numbers $\left(\mathrm{cm}^{-1}\right)$ was used to prepare basic reference system for the comparison between the inorganic chemical structure of natural teeth and different solid fragments released during mastication. According to different chemical compositions of hard dental tissues, enamel and dentin were analyzed. The supragingival dental calculus was also taken into consideration. The received IR spectra of compounds were reported as percentage transmittance values as a function of wave number in $\mathrm{cm}^{-1}$. The next IR spectra of natural tooth (enamel, dentin) and dental calculus were presented in Fig. 1.

The typical peaks were found at around 566, 603 and $1028 \mathrm{~cm}^{-1}$ associated with phosphate ion - $\mathrm{PO}_{4}^{3-}$ (very intensive, broad band). Moreover, within the broad absorption band (the peak at $1028 \mathrm{~cm}^{-1}$ ) the characteristic dominant band at $872 \mathrm{~cm}^{-1}$ was exhibited which was attributed to carbonate ion $\left(\mathrm{CO}_{3}^{2-}\right)[2,32]$. These IR spectra also included the most intense peaks at 1415 and 1457, 1547, $1640 \mathrm{~cm}^{-1}$ which can be linked to carbonate ion $\left(1415\right.$ and $\left.1457 \mathrm{~cm}^{-1}\right)$, next amide II (-CO-NH-) and amide I (-CO- $\left.\mathrm{NH}_{2}-\right)$ groups, respectively [19, 33, 34]. The differences which followed from IR spectra of natural teeth from patients of various ages were shown in Fig. 2.

These spectra were similar in the entire $400-4000 \mathrm{~cm}^{-1}$ region, however the intensity variations of the band at $1415-1641 \mathrm{~cm}^{-1}$ caused by organic polypeptides were observed. The intensities of the carbonate band $\left(872 \mathrm{~cm}^{-1}\right)$ decreased with age. Hence, the intensity of this band was the highest for deciduous teeth and gradually decreased with age in permanent teeth. Identical relationship with age concerning carbonate ion $\left(1415,1457 \mathrm{~cm}^{-1}\right)$, amide II $\left(1547 \mathrm{~cm}^{-1}\right)$ and amide I $\left(1641 \mathrm{~cm}^{-1}\right)$ was proved $[19,33]$. 


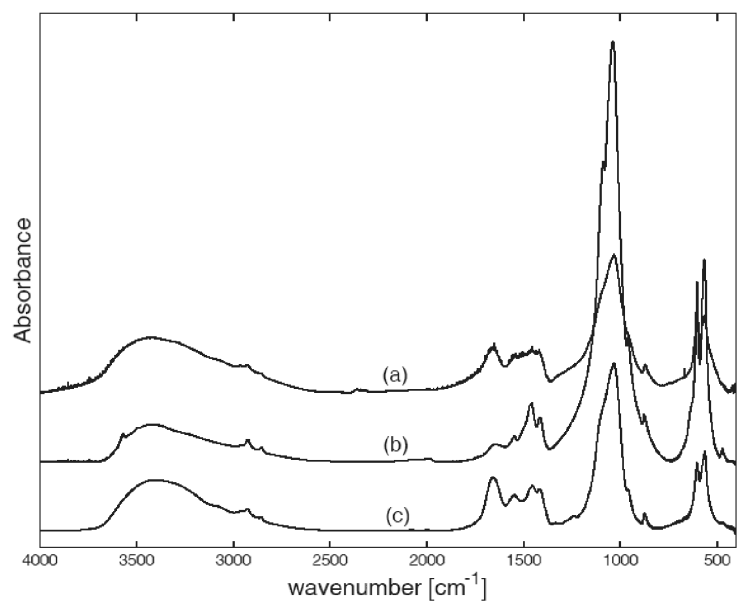

Fig. 1. IR spectra of dental calculus and 14 tooth (20-year-old patient): (a) supragingival dental calculus, (b) enamel, (c) dentin. The spectra were shifted for clarity.

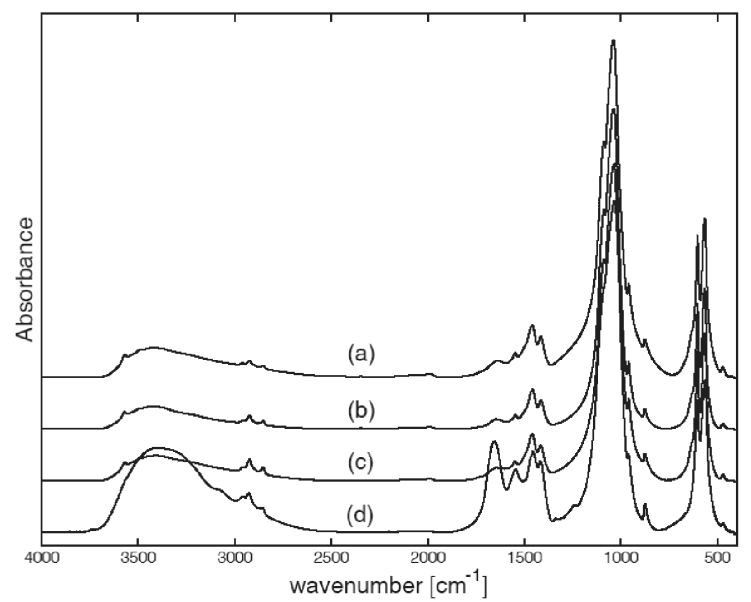

Fig. 2. IR spectra of teeth from donors of various ages: (a) tooth 48, 50-year-old patient, (b) tooth 38, 24-year-old patient, (c) tooth 14, 13-year-old patient, (d) tooth 74, 9-year-old patient.

The database of infrared spectra comprising the twenty most commonly employed dental materials was prepared. In Fig. 3 the IR spectra of inorganic dental materials (porcelain, amalgam) and components $\mathrm{SiO}_{2}, \mathrm{CaCO}_{3}$ and $\mathrm{Ca}_{3}\left(\mathrm{PO}_{4}\right)_{2}$ (Cerasorb, Curasan, Kleinostheim, Germany) were depicted.

The IR spectrum of amalgam revealed lack of absorption bands in applied range of wave numbers but in the remaining observed spectra the bands at 9401119, 551 and $605 \mathrm{~cm}^{-1}$ were related to phosphate ion $\left(\mathrm{PO}_{4}^{3-}\right)$. In IR spectra of porcelain and $\mathrm{SiO}_{2}$ the similarities were found at 459-465, 668-720, and 


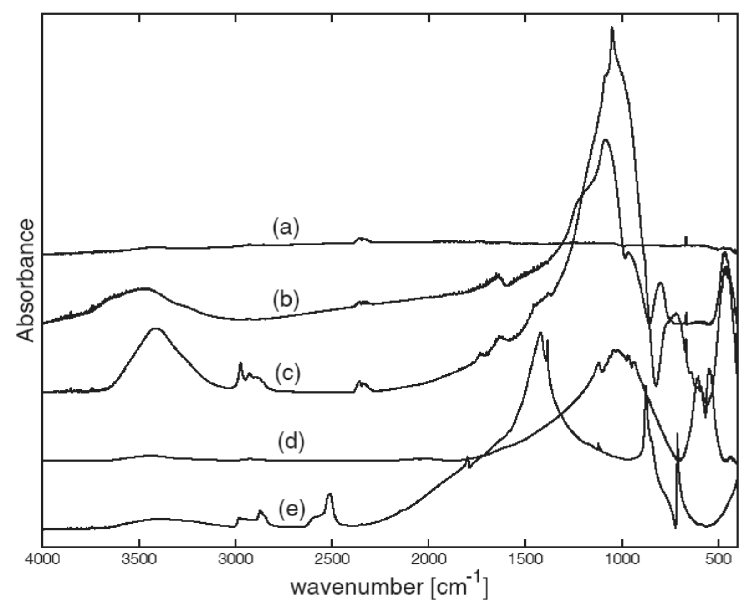

Fig. 3. IR spectra of inorganic compounds and inorganic dental materials: (a) amalgam, (b) $\mathrm{SiO}_{2} \cdot 18 \mathrm{H}_{2} \mathrm{O}$, (c) porcelain, (d) Cerasorb, (e) $\mathrm{CaCO}_{3}$.

$1050 \mathrm{~cm}^{-1}$. Moreover, in spectrum of porcelain a band of the group $\mathrm{Si}-\mathrm{OH}$ was observed at $3410 \mathrm{~cm}^{-1}$. The typical absorption band at $1725-1727 \mathrm{~cm}^{-1}$ region caused by ester group and peaks at 466, $1084 \mathrm{~cm}^{-1}$ and $3420 \mathrm{~cm}^{-1}$ due to intensive band of $\mathrm{SiO}_{2}$ and $\mathrm{Si}-\mathrm{OH}$ group, respectively, were identified in spectra of compomers in Fig. $4[12,16]$.

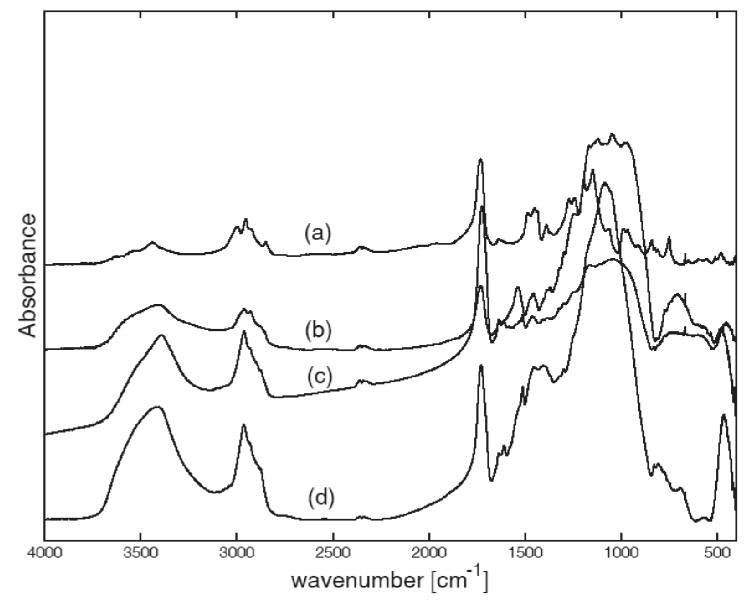

Fig. 4. IR spectra of acrylic material and compomers: (a) acrylic tooth-Dentex, (b) Dyract eXtra, (c) Hytac, (d) Twinky Star.

It is clear from comparative IR spectrum of artificial acrylic tooth (Fig. 4) that there was no absorption band corresponding to inorganic components but the presence of ester group $\left(1731 \mathrm{~cm}^{-1}\right)$ and polyethylene $-\mathrm{CH}_{2}-$ group 
(2952-2996 $\left.\mathrm{cm}^{-1}\right)$ were confirmed, respectively. Many similarities in IR spectra of composite materials and fissure sealants were shown in Fig. 5.

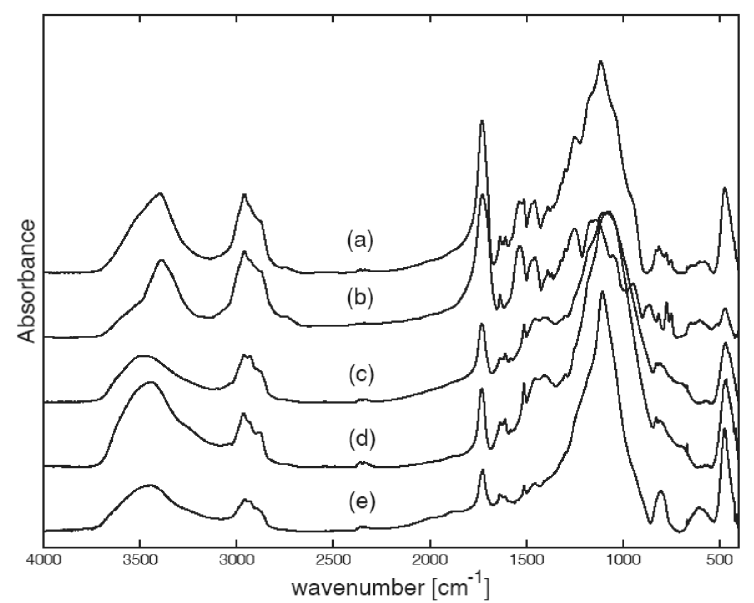

Fig. 5. IR spectra of fissure sealants and composite materials: (a) Helioseal F, (b) Conseal f, (c) Venus, (d) Herculite XRV, (e) Valux Plus.

The observed spectral features were related to chemical structure of poly [methyl methacrylate] with inorganic fillers. The IR spectra of glass ionomers were shown in Fig. 6.

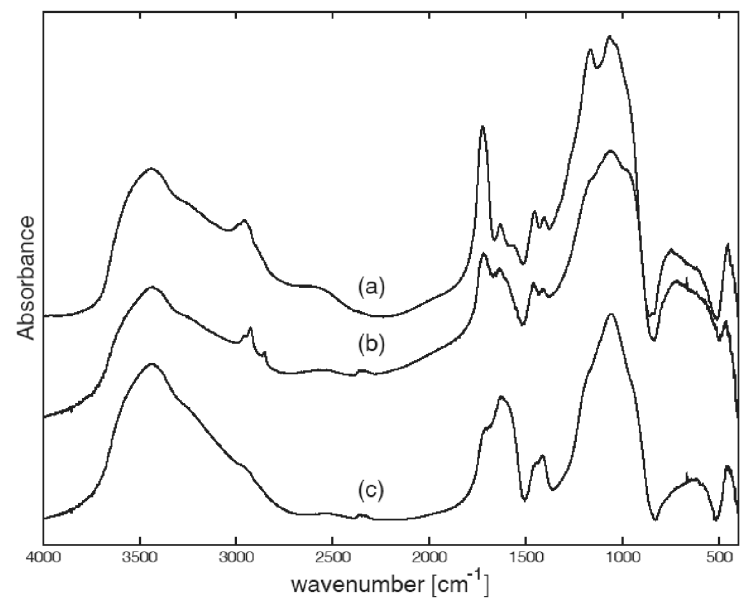

Fig. 6. IR spectra of glass ionomers: (a) Vitremer, (b) GC Fuji IX, (c) Ketac-Molar.

The bands at 1725 (Fig. 6-(a), 1721 (Fig. 6-(a,b) and 1630-1703 cm ${ }^{-1}$ corresponded to ester groups of poly(methylxylene) or amide I, II groups (Fig. 6-(c) $[15,17]$. Moreover, IR peaks at 1067, 747, $454 \mathrm{~cm}^{-1}$ (Fig. 6-(a), at 1065, 668, 
$452 \mathrm{~cm}^{-1}$ (Fig. 6-(b), at 1055, 657, $452 \mathrm{~cm}^{-1}$ (Fig. 6-(c) due to aluminum silicate were observed. All spectra manifested absorption peaks which can be linked to $\mathrm{Si-}-\mathrm{OH}$ at $3435,3445,3439 \mathrm{~cm}^{-1}$, simultaneously but some effect of water can be interfering. The next seven IR spectra of composite materials were presented in Fig. 7 and exhibited strong IR bands at $1726-1728 \mathrm{~cm}^{-1}$ corresponding to the ester group $\left(-\mathrm{COOCH}_{3}\right)$. These bands are assigned to organic matrix i.e. Bis-GMA, Bis-EMA, UDMA, TEGDMA [35].

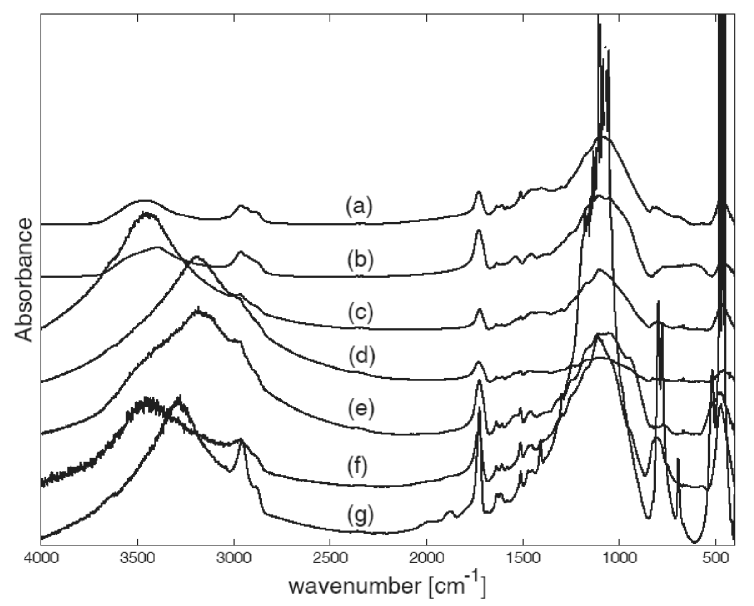

Fig. 7. IR spectra of composite materials and compomer: (a) Charisma, (b) Compoglass F, (c) Tetric Ceram, (d) Tetric Flow, (e) Ariston pHc, (f) Filtek Z250, (g) Pertac II.

Thus, this analysis confirmed the presence of poly [methyl methacrylate]. Moreover, the bands at 744 and $1087-1144 \mathrm{~cm}^{-1}$ associated with inorganic components were detected.

\section{Discussion}

In our study the IR spectroscopy was conducted as a useful and available method for quick identification of chemical compounds. Some of the researchers $[2,4-6,14,16,18,21,22]$ have concentrated on the Raman spectroscopy but the Raman method and IR spectroscopy are considered to be complementary [2]. The IR spectroscopy can be a useful method to identify some fragments of solid substances so as to confirm their origin. Moreover, we can identify foreign bodies in the mouth which can promote inflammation, e.g. an abscess, also is useful not only in numerous litigations against criminals but might be helpful in other cases in forensic medicine e.g. to identify cadavers. According to Wrigley Poland Ltd there have been 10 to 15 questionable cases per year, since 2001. Since that time fragments of tooth structure or other contaminations were defined in the samples of chewing gum whereas existence of dental materials was observed only in two specimens. 
Thus, the analysis of IR spectra both of the fragments of natural tooth and different dental materials could be essential. In this investigation IR spectrum of dentin was compared with that of enamel. The intensity of tooth IR absorption band is determined by the presence of hydroxyapatite $\mathrm{Ca}_{10}\left(\mathrm{PO}_{4}\right)_{6}(\mathrm{OH})_{2}$ which constitutes $95-97 \%$ of enamel and $70-75 \%$ of dentin. The tooth mineralization process leads to the formation of pure hydroxyapatite and hydroxyapatite containing carbonate ion $\left(\mathrm{CO}_{3}^{2-}\right)$, and can be described by the chemical formula $\mathrm{Ca}_{10}\left[\left(\mathrm{PO}_{4}\right)_{6-x}\left(\mathrm{CO}_{3}\right)_{x}\right]\left[(\mathrm{OH})_{2-y}\left(\mathrm{CO}_{3}\right)_{y}\right]$ with $x \approx 0.039$ and $y=0.001$ [36]. Concerning the mineralization process of dental calculus, which is composed of various mineral phases of calcium phosphate, the supragingival dental calculus was analyzed by IR spectroscopy. It has been reported previously that the calcification mechanism of calculus is similar to that of dental hard tissues [34]. We observed evident spectral differences between intensity of absorption band due to $\mathrm{CO}_{3}^{2-}$ in the enamel, dentin and dental calculus. The intensity of this band is the highest in the dentin unlike enamel and dental calculus. The same dependence concerns organic components due to the presence of about $30 \%$ of aqueous-organic gel in the dentin. Thus the absorption band caused by dentin organic substances is stronger than the one caused by enamel and dental calculus. As the previous study has shown, the microspectrometric technique can be used in order to improve accurate analysis of synthetic and biological carbonated apatites. The use of this method can be explained by the fact that small amounts of carbonate ions are contained in dental hard tissues [2]. FTIR microspectroscopy was also performed to compare both dentin revealed from the tooth and dentin produced in vitro [37]. Regarding teeth's age several studies have reported on carbonate and phosphate ions related to its maturation $[32,38,39]$. As a result of enamel remineralization initiated by fluorization, the fluorine ion can substitute hydroxide ion and form the least soluble apatite, i.e. fluoroapatite $\mathrm{Ca}_{10}\left(\mathrm{PO}_{4}\right)_{6}(\mathrm{OH}) \mathrm{F}$. In fact, IR band of this apatite was not observable in our IR spectra.

IR spectrum of inorganic dental materials lacks absorption bands due to organic polypeptides which are assigned to chemical structure of natural teeth. This spectrum is characterized by a scanty, low-intensity absorption, typical of inorganic compounds. Quartz $\left(\mathrm{SiO}_{2}\right)$, feldspar $\left(\mathrm{K}_{2} \mathrm{O} \cdot \mathrm{Al}_{2} \mathrm{O}_{3} \cdot 6 \mathrm{SiO}_{2}\right)$ and kaolin $\left(\mathrm{Al}_{2} \mathrm{Si}_{2} \mathrm{O}_{5}(\mathrm{OH})_{4}\right)$ are the mineral constituents of traditional porcelain [40]. In our study the observed porcelain spectral feature at $1050 \mathrm{~cm}^{-1}$ is due to $\mathrm{SiO}_{2}$. The same FTIR spectrum was shown in porcelain contact layer at $1020 \mathrm{~cm}^{-1}$ and silica coating-porcelain interlayer at $1040 \mathrm{~cm}^{-1}$ (assigned to Si-O) during examination of metal-ceramic joints [12].

Chemical structure of dental materials derived from organic compounds (e.g. polymethacrylic derivatives) exhibits a specific rich, intense infrared spectrum which allows to identify typical functional groups (e.g. ester at $1740 \mathrm{~cm}^{-1}$, amide at $1650 \mathrm{~cm}^{-1}$, aromatic $\mathrm{C}-\mathrm{H}$ stretch at $2900 \mathrm{~cm}^{-1}$, alifatic $\mathrm{C}-\mathrm{H}$ stretch at $2900 \mathrm{~cm}^{-1}$, amine NH stretch at $3400 \mathrm{~cm}^{-1}$ ). The previously reported examina- 
tions confirm the utility of IR spectroscopy for assessing the chemical and physical changes of such dental materials as compomers, composite and glass ionomers. The rich IR spectrum of compomers e.g. Dyract eXtra (UDMA, TEGDMA) results from organic polymer matrix included in aromatic or urethane diacrylate oligomer such as e.g. bisphenyl-glicydyl methacrylate (Bis-GMA). In addition, the authors identified dimethacrylate components in analyzed composites and fissure sealants, e.g. Valux Plus (Bis-GMA, TEGDMA) and Helioseal F (Bis-GMA, UDMA). The relationship between chemical structure using monomers (dimethacrylate: bisphenol A glycol dimethacrylate (Bis-GMA)), bisphenol A ethoxylated dimethacrylate (Bis-EMA), urethane dimethacrylate (UDMA), triethylene glycol dimethacrylate (TEGDMA) and the degree of conversion by means of IR spectroscopy was discussed in the literature [35, 41]. In the separate study amino acid acrylate and methacrylate derivatives were detected as appropriate to synthesize non-cytotoxicity HEMA-free glass ionomer cements [16]. FTIR analysis was conducted as a supportive method to evaluate tribochemical reactions between composite fillers and water. This technique is insufficient to assess chemical reactions but can be used as an additional tool to supplement other methods [10]. This procedure also permitted to determine spectral changes of composite materials after the pressure was applied. As mentioned previously, the fluorine ion can substitute hydroxide ion and form the least soluble, fluoroapatite. This form of the apatite seems to be resistant to acids, thus the cariostatic mechanisms of fluoride are still being investigated [42]. Accordingly, the restorative materials which release fluorine ions are commercially available. Therefore, the authors examine possible adverse effects of fluoride on dental materials. In this research FTIR spectroscopy was performed [28].

The overall applications which attempted to use the vibrational tools have also been reported by researchers $[7,8,13,14,17]$. As a consequence, the review of the literature and our results present the opportunity for further examinations.

\section{Conclusion}

We conclude from our study that IR spectrum of natural dental structures differs radically from those of synthetic materials and is characterized by a scanty, low-intensity absorption, typical of inorganic compounds. The prepared database of infrared transmission spectra included 23 frequently employed dental materials, facilitating their appropriate identification. The application of infrared spectroscopy allowed for a quick differential identification of typical dental materials produced from organic compounds for inorganic restorations (e.g. porcelain) and of tooth structure-resembling hydroxyapatite and its contaminate forms with fluoride and carbonate ions. From our study as well as the literature reviewed it appears that investigators uniformly confirm the benefits of IR spectroscopy concerning identification of chemical functional groups of different chemical compositions. 


\section{Acknowledgments}

This investigation was supported in part by Wrigley Poland Ltd.

\section{References}

[1] B.C. Ling, P. Nambiar, K.S. Low, C.K. Lee, J. Forensic Odontostomatol. 21, 17 (2003).

[2] G. Penel, G. Leroy, C. Rey, E. Bres, Calcif. Tissue Int. 63, 475 (1998).

[3] M. Jackson, H.H. Mantsch, J. Mol. Struct. 408/409, 105 (1997).

[4] G. Pezzotti, Anal. Bioanal. Chem. 381, 577 (2005).

[5] B. Schrader, B. Dippel, I. Erb, S. Keller, T. Löchte, H. Schulz, E. Tatsch, S. Wessel, J. Mol. Struct. 480-481, 21 (1999).

[6] H. Tsuda, J. Arends, Adv. Dent. Res. 11, 539 (1997).

[7] I.D. Ana, S. Matsuya, M. Ohta, K. Ishikawa, Biomaterials 24, 3061 (2003).

[8] H. Fong, S.H. Dickens, G.M. Flaim, Dent. Mater. 21, 520 (2005).

[9] R.H. Halvorson, R.L. Erickson, C.L. Davidson, Dent. Mater. 19, 327 (2003).

[10] V.S. Nagarajan, S. Jahanmir, V.P. Thompson, Dent. Mater. 20, 63 (2004).

[11] J.W. Nicholson, E. Gjorgievska, B. Bajraktarova, J. Oral Rehabil. 30, 601 (2003).

[12] C. Paluszkiewicz, A. Stoch, Vibrat. Spectrosc. 35, 183 (2004).

[13] J.W. Stansbury, S.H. Dickens, Dent. Mater. 17, 71 (2001).

[14] M. Suzuki, A. Fujishima, T. Miyazaki, H. Hisamitsu, K. Kojima, Y. Kadoma, Biomaterials 20, 839 (1999).

[15] D. Xie, I.D. Chung, W. Wu, J. Mays, Dent. Mater. 20, 470 (2004).

[16] J. Xu, I.S. Butler, D.F.R. Gibson, I. Stangel, Biomaterials 18, 1653 (1997).

[17] H.K. Yip, W.M. To, Dent. Mater. 21, 695 (2005).

[18] K.S. Kalasinsky, V.F. Kalasinsky, Spectrochim. Acta A Mol. Biomol. Spectrosc. 61, 1707 (2005).

[19] A. Carden, M.D. Morris, J. Biomed. Opt. 5, 259 (2000).

[20] E.P. Paschalis, E. DiCarlo, F. Betts, P. Sherman, R. Mendelsohn, A.L. Boskey, Calcif. Tissue Int. 59, 480 (1996).

[21] H. Tsuda, J. Ruben, J. Arends, Eur. J. Oral Sci. 104, 123 (1996).

[22] H. Tsuda, J. Arends, J. Dent. Res. 73, 1703 (1994).

[23] G.W. Marshall Jr, Quintessence Int. 24, 606 (1993).

[24] R.L. Frost, K.L. Erickson, Spectrochim. Acta A Mol. Biomol. Spectrosc. 61, 45 (2005).

[25] W. Paszkowicz, B.J. Kowalski, E.A. Görlich, Z. Kaszkur, J. Alloys Comp. 401, 1 (2005).

[26] S.E.P. Dowker, J.C. Elliott, G.R. Wilson, P. Cloetens, Eur. J. Oral Sci. 114, 353 (2006).

[27] A. Franz, F. König, M. Anglmayer, X. Rausch-Fan, G. Gille, W.-D. Rausch, T. Lucas, W. Sperr, A. Schedle, Dent. Mater. 19, 382 (2003). 
[28] L. Papagiannoulis, J. Tzoutzas, G. Eliades, J. Prosthet. Dent. 77, 405 (1997).

[29] N. Martin, N.M. Jedynakiewicz, A.C. Fisher, Dent. Mater. 19, 77 (2003).

[30] C. Zantner, A.M. Kielbassa, P. Martus, K.-H. Kunzelmann, Dent. Mater. 20, 277 (2004).

[31] N.S. Koupis, L.C. Martens, R.M.H. Verbeeck, Dent. Mater. 22, 1045 (2006).

[32] C. Rey, M. Shimizu, B. Collins, M.J. Glimcher, Calcif. Tissue Int. 46, 384 (1990).

[33] M.E. Fleet, X. Liu, Biomaterials 28, 916 (2007).

[34] M. Kakei, H. Nakahara, M. Kumegawa, M. Yoshikawa, S. Kunii, Biochim. Biophys. Acta 1524, 189 (2000).

[35] I. Sideridou, V. Tserki, G. Papanastasiou, Biomaterials 23, 1819 (2002).

[36] A.A. Romanyukha, M.F. Desrosiers, D.F. Regulla, Appl. Radiat. Isotopes 52, 1265 (2000).

[37] I. About, M.J. Bottero, P. de Denato, J. Camps, J.C. Franquin, T.A. Mitsiadis, Exp. Cell Res. 258, 33 (2000).

[38] C. Rey, V. Renugopalakrishnan, M. Shimizu, B. Collins, M.J. Glimcher, Calcif. Tissue Int. 49, 259 (1991).

[39] C. Rey, M. Shimizu, B. Collins, M.J. Glimcher, Calcif. Tissue Int. 49, 383 (1991).

[40] S.R. Bragança, C.P. Bergmann, J. Eur. Ceram. Soc. 24, 2383 (2004).

[41] R.M. Guerra, I. Durán, P. Ortiz, J. Oral Rehabil. 23, 632 (1996).

[42] U. Kaczmarek, Czas. Stomatol. 58, 404 (2005). 